\title{
LEGAL TOOLS IN INTERNATIONAL ENVIRONMENTAL LAW
}

\section{PRÁVNE NÁSTROJE \\ V MEDZINÁRODNOM ENVIRONMENTÁLNOM PRÁVE}

\author{
Zoltán SZIRA* - Hani ALGHAMDI* - Erika VARGA* - Kinga BÁRDOS**
}

\section{The sources of international law}

Since there is no world government, there is no world Congress or parliament to make international law the way one country is formed by domestic legislatures. As such, there can be some difficulties in deciding precisely what international law is. There is no "Code of International Law". Although there is an International Court of Justice and a number of specialized international courts and tribunals, their authority is fundamentally dependent on state approval and they lack what can properly be defined as compulsory jurisdiction of the kind that national courts possess. The consequence is that the acts of the 192 states that make up the international community make international law essentially on a decentralised basis. The Statute of the International Court of Justice mentions these sources:

- Treaties between States;

- Customary international law derived from the practice of States;

- General principles of law recognized by civilised nations; and, as subsidiary

- Judicial decisions and the writings of "the most highly qualified publicists".

\section{Abstract (EN)}

Environmental law concepts are expressed in conventions, international binding laws, state practice and soft law commitments. They may be applicable to all foreign community members. These are widely recognized and even approved in the practice of the state.

A special feature of international environmental law is that many environmental issues are governed by non-binding soft-law instruments that allow faster responses to international environmental issues. Governments tend to resist legally binding treaty regulation for different reasons but are much more likely to adopt a written action plan or resolution, at least voicing a political will to address an issue. The numerous constitutional standards of several countries must be followed when negotiating international agreements: for example, the way the national parliament must approve and enforce a treaty. The paper investigates the regulation system of international environmental law.

\section{Keywords (EN)}

international treaty, environment, law, agreement
Although this article is only directed at the International Court of Justice, it has developed over

the years into a widely accepted definition of what the origins are in international law. It also explains how States should establish new international law and enforce it.

Treaties are the strongest and the most binding category as they represent consensus agreements among the signatory countries. Treaties are similar to contracts between countries; agreements are shared, negotiated in writing, and signed between states. States may discuss the interpretation or implementation of a treaty, but the treaty's written provisions are binding. Treaties can address a variety of areas such as trade relations, such as the North American Free Trade Agreement, or nuclear arms control, such as the Nuclear Non-Proliferation Treaty. They can be either bilateral (between two countries) or multilateral (between many countries). They can have their own rules for enforcement, such as arbitration, or refer enforcement concerns to another agency, such as the International Court of Justice. The rules concerning how to decide disputes relating to treaties are even found in a treaty themselves- the Vienna Convention on the Law of Treaties ${ }^{(1)}$.

(1) United Nations (1969)

\section{Abstrakt (SK)}

Koncepty environmentálneho práva sú zakotvené $\mathrm{v}$ dohovoroch, medzinárodne záväzných právnych aktoch, $v$ štátnej praxi a tiež v záväzkoch tzv. soft law. Takéto koncepty sa môžu vzt’ahovat' na všetkých členov zahraničnej komunity, sú všeobecne uznávané a dokonca schválené v praxi štátu. Zvláštnostou medzinárodného práva životného prostredia je, že mnohé environmentálne otázky sa riadia nezáväznými nástrojmi tzv. soft law, ktoré umožňujú rýchlejšie reakcie na medzinárodné environmentálne problémy. Vlády majú tendenciu bránit sa právne záväzným zmluvným nariadeniam z rôznych dôvodov. Na druhej strane je ovela pravdepodobnejšie, že prijmú písomný akčný plán alebo uznesenie, ktoré prinajmenšom vyjadrí politickú vôlu problém riešit'. Pri vyjednávaní medzinárodných zmlúv sa musia dodržiavat’ početné ústavné normy viacerých krajín: napríklad spôsob, akým musí národný parlament schválit' a uviest' zmluvu do platnosti. Príspevok skúma systém regulácie medzinárodného práva životného prostredia.

\section{Klưčové slová (SK)}

medzinárodná zmluva, životné prostredie, právo, dohoda

\footnotetext{
Hungarian University of Agriculture and Life Sciences, Hungary.

** Esterházy Károly Catholic University, Hungary.
} 
Strictly speaking a treaty is not so much a source of legislati;on as a source of lawful duty. Treaties are only binding on States who are parties to them and choosing whether or not to become a party to a treaty is solely one for the State - there is no obligation to sign a treaty. Customary international law, pacta sunt servanda, requires all States to respect their treaties. That is why treaties are defined more accurately as sources of lawful obligation. But as authoritative statements of customary law, several treaties are relevant, too. A treaty that is openly signed between a large number of states is also seen as writing down what previously unwritten customary law rules were. Clearly this is the case where a clause of the treaty is meant to codify existing law. In principle, where a provision of a treaty codifies a rule of customary law the basis of law is the original practice and opinio juris - the provision of a treaty is merely evidence. But this overlooks the fact that it updates the rule by writing down a rule that was previously unwritten. From that point on, it is the written law that everybody must look at, and questions about the nature of the regulation must concentrate mostly on interpreting the text rather than examining the underlying procedure. In reality the fact that a large number of States agree on a clause of a treaty is itself an important piece of state practice. If subsequently those and other states enforce the provision of the treaty - particularly where they are not parties to the treaty - then it can quickly become part of customary international law.

The rules of customary international law slowly developed to reflect the changing international community. Before the Second World War - and before international law was specifically documented after the war as written international agreements - customary law was deemed to develop gradually and involve sincere action from the majority of States. The notion was that when a certain foreign practice is considered by the majority of states to be legally binding (opinio juris), it eventually transforms into a lawfully binding statute.

Such a custom shall be universal and essentially systematic and shall endure for some time. States will always believe they follow a custom as they are bound by a legal rule to do so. In comparison, in other fields of international cooperation, other rituals and procedures are practiced, but not because States find them legally binding.

It is more difficult to determine customary international law (CIL) than the terms of a signed treaty. CIL is created by the actual acts of states (called "state practice") as they show that certain states believe it would be unlawful to behave otherwise. Even if the CIL rule isn't written, it still links states and expects them to obey it. For example, countries have provided ambassadors protection for thousands of years. As far back as ancient Greece and Rome, when on their diplomatic missions, ambassadors from another nation were not affected, even though they represented a country at war with the country in which they were situated. Many countries have publicly stated throughout history that they agree that this protection should be granted to the ambassadors. So, if a country hurt an ambassador today it would be in breach of customary international law. Similarly, in modern history, governments have accepted by their acts and comments that killing civilians deliberately during wartime is unlawful under international law. However, deciding CIL is complicated, as it is not written down in rela- tion to a treaty. Certain rules are so commonly followed and accepted by many states as law, that there is little question that CIL exists with respect to them; but other laws are not as generally known and there are disagreements as to whether or not they are actually CIL.

If states negotiate a legally binding global convention, they are actually signalling their willingness to be bound by certain rules. States are continually sharing their opinions about how other states will act within international organizations, and in other forums. The manner in which states 'talk' and the formal commitments they make are becoming increasingly relevant for the implementation of modern international law. International laws are being drawn up at a increasing rate, both by treaties and through other international instruments.

Customary international law is not an effective method for reacting to threats to the environment since it is always subject to interpretation. Environmental issues should be tackled as soon as possible and handled in a manner that is fluid and capable of being adjusted to the latest science.

One advantage of customary international law is that it binds every country in the world, while treaties bind only the parties to them: thus, for example, if 150 states are parties to a global convention, more than 40 states remain outside the system. If it can be proved and tested that most of the principles of the convention have evolved into customary international law, then the principles will be legally binding on all the world states. Even if a state withdrawn from the treaty in question, the customary international law will still remain legally binding ${ }^{(2)}$.

The third source of international law is focused on the "natural law" principle, which claims that laws are a result of the instinctual conviction that certain actions are right and other actions are wrong. For example, most legal systems respect "good faith," that is to say the idea that everyone intends to abide by the agreements they make. In certain countries, courts will investigate whether the parties to a case have behaved in good faith, and take this question into account when determining a matter.

The last two sources of international law are considered to be subsidiary means for deciding rules of law. Although these sources are not international law by themselves, when combined with proof of international practice or general principles of law, they may help to prove the existence of a particular rule of international law.

Judicial rulings, both at the International Court of Justice (ICJ) and at national courts, are especially important. The ICJ, as the main legal body of the United Nations, is considered to be an authoritative expounder of law, and when other countries' national courts begin to recognize a certain principle as a legal rationale, this may signal a wide-ranging acceptance of that principle, such that it can be considered part of international law.

Legal scholarship, on the other hand, is not in itself completely authoritative, but may characterize rules of law commonly followed around the world. Thus, law professors may consult articles and books to find out what international law is.

\footnotetext{
(2) Koivurova (2014).
} 


\section{Agrárne}

Figure 1: List of parties to the Vienna Convention on the Law of Treaties

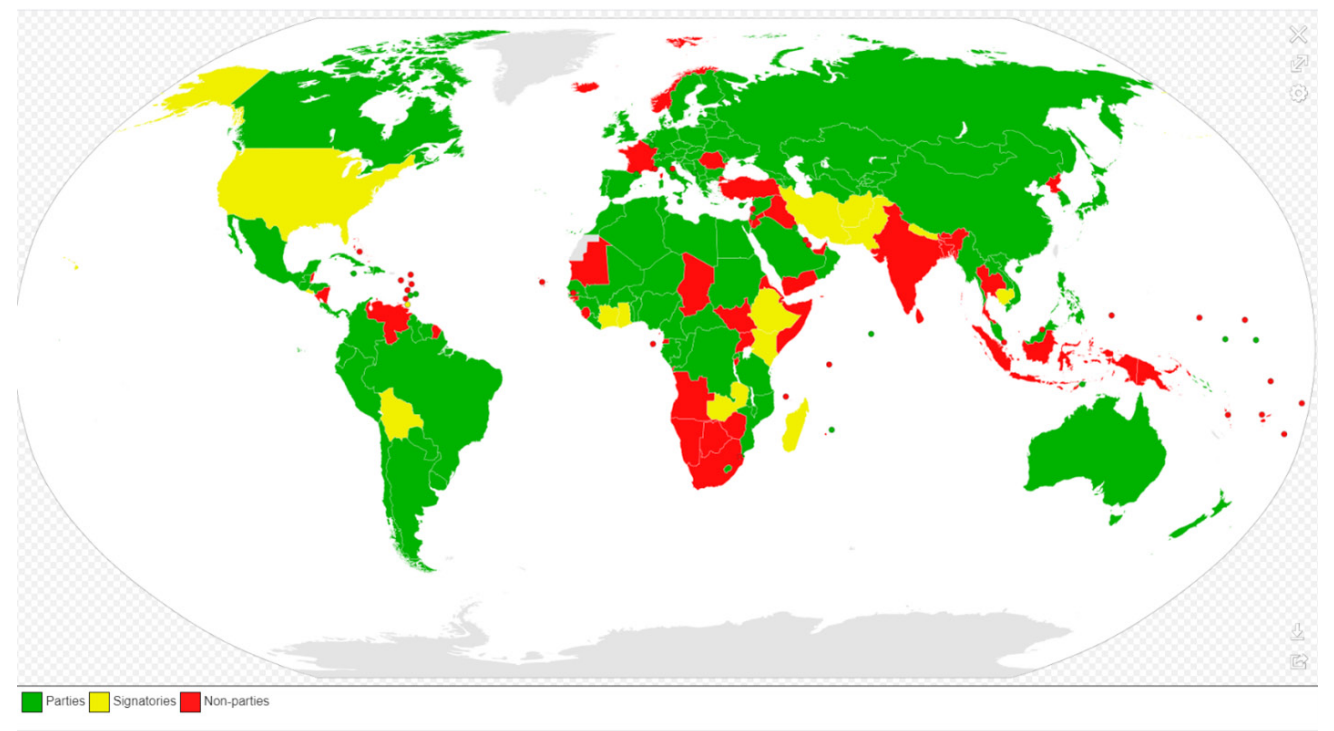

Source: UN (1969)

\section{International agreements}

Since World War II, the primary source of international law has been international treaty law, as States have signed a large number of conventions. For the international community that had previously been governed largely by customary international law this was a significant shift. States will now read the laws regulating their actions in written treaties. The previous ambiguous and unwritten laws of customary law were far from perfect, since the exact responsibilities of states were still undefined.

There are several terms of international written multilateral agreements: pact, treaty, convention, agreement and protocol. All of them are governed by customary international law applicable to all treaties; these principles apply in situations where the parties themselves do not categorize a matter in an agreement. The Vienna Convention regulates the adoption, modification, interpretation and many other matters relating to all written treaties. As of April 2020, the Convention includes 116 parties and a further 15 states have signed but have not ratified the convention (Figure 1). The International Court of Justice has noted in many rulings that all of its articles codify customary international law. By virtue of Article 18 of the Vienna Convention, when states conclude a treaty, they undertake "not to defeat the object and purpose of a treaty before it enters into force.' This is an important point to recognize. Newspapers and newspapers often refer to the parties to a treaty as their signatories, which is an incorrect term indeed. Signing a treaty is not synonymous with being a party, although states often agree that it is only by signature that an agreement is binding. A procedure is generally accompanied by a first signing of an agreement by states to show their goodwill and intention to become a party in the immediate future. Following signing, the agreement joins each state's national legislative framework according to its domestic constitutional law. When the State is prepared to be bound by the treaty, it shall be deposited with the body defined in the agreement.

However, even ratifying an environmental treaty cannot automatically result in the immediate binding of a state or states. An international treaty must also come into effect. Some treaties may define a minimum number of states that are expected to become parties to the agreement before they can enter into force.

In general, a multilateral environmental treaty proceeds as follows:

- At the negotiation stage: In addition to drafting the substantive obligations, it also addresses how to implement the final text in the treaty, how to convey the will to become a member, when the treaty is binding on a state, and the conditions under which it can enter into force internationally. A particular article also defining how states become a full party to a treaty. If a state signs a treaty, it must abstain from acts that would undermine the aim and intent of that treaty, even before it enters into force. Because a state does not become a party to a treaty by merely signing it, the treaty does not yet become fully legally binding on that state.

- After signing: several states have to send the treaty for approval to their own national Parliament. The state then signals its agreement to be bound by a treaty depositing the instrument of ratification with the depositary defined in the treaty (as provided for in the treaty). The treaty also specifies a limited period of time between depositing the ratification instrument and accepting the state as a member. Specifically, in the case of global environmental treaties, states may become directly parties, bypassing both the negotiation stage and the signing act. Typically, the process is referred to as accession.

- Entry into force: several treaties also prescribe a minimum number of ratifying states needed to put the treaty 
into international force. This is primarily because adopting the treaty is pointless before a sufficiently significant number of states have engaged in the fight against the international environmental problem at problem ${ }^{(3)}$.

Modern environmental treaties parties appear to define in more and more detail how the terms are to be interpreted, thus reducing the ability of states to interpret them in such a narrow way as to reduce their obligations. Most environmental treaties do not recognize reservations, for the same reason. On the other hand, most environmental treaties are fairly weak; in the case of a conflict, they do not impose an obligation to account for environmental harm or include compulsory dispute resolution between the parties. Most of the documents were designed to be so ambiguous they were merely a very openended obligation.

\section{Implementation of the international agreements}

International environmental law varies from traditional international law in the way it compels the parties to an international environmental agreement to meet their commitments in action. In general, international law, the principal rule is that if state A violates its duty, the injured state B can take the following measures:

- State B can first attempt at a political settlement of the dispute: that is, through negotiation, or through third party mediation.

- If still unsatisfied, state B may, with the consent of the parties to the dispute, bring the dispute before an arbitration court or an international court of justice; in most cases, states will seek to resolve the dispute themselves by negotiation rather than sending it to court proceedings.

- In certain situations, the injured state can respond only by countermeasures to a breach of the treaty. Countermeasures are acts taken by the injured state that would ordinarily be contrary to international law; they are rendered lawful because they are a justified reaction to the earlier violation of statement A. In many cases, the obvious result is a vicious spiral: state A denies having breached its obligations towards state B, and in turn takes its own countermeasures in response to state B's measure.

These procedures can hardly push international legislation on the environment forward. The goal is to combat or even remove an external threat to the Therefore, it is vital to avoid mutual disputes as far as possible relating to non-observance of the regulations of the treaty. Most of the environmental treaties do contain a dispute resolution paragraph. But usually this only allows states to settle their differences by the means they find acceptable themselves.

Environmental treaties take a different path and seek to resolve violations by joint commissions of enforcement. A meeting of the parties usually sets out the monitoring protocols and nominates an implementation committee responsible for developing ways of managing breaches such that they do as (3) Ibid. little harm as possible to the overall functioning of the agreement framework. Implementation of a treaty (and potential breaches) is reviewed by the negotiating committee and/or at the parties' meetings. Such committees will work only if they are briefed on how states are dealing with their obligations. They will obtain the information as unbiased as possible. This is a difficult system, but environmental treaties have slowly succeeded in establishing processes that at the very least provide clearer details about how treaties are implemented and enacted by states. The state reports go either to the parties' conference, to the treaty secretariat, or directly to the implementing committee. Expert panels can be used on the most ambitious environmental treaties. For example, in the climate regime, Annex I states' greenhouse gas emissions and sink inventories are first certified by the secretariat, and then by the panel of experts. When the panel of experts is dissatisfied with the inventory of a department, queries will be referred to the compliance committee ${ }^{(4)}$.

The total number of international environmental agreements is impressive: Since 1945, more than 2,000 environmental agreements and protocols have been signed ${ }^{(5)}$. Some of the oldest IEAs regulate fisheries, endangered species, agriculture and wetlands, but a growing proportion of IEAs now tackle habitat protection, energy generation, hazardous waste, and pollutant emissions $^{(6)}$.

In addition to those international environmental agreements, preferential trade agreements (PTAs) are gradually contributing to global governance of the environment. Modern PTAs usually provide a fully-fledged environmental protection portion, with responsibilities that are often more precise and stricter than those found in IEAs ${ }^{(7)} \cdot 94.3 \%$ of PTAs concluded since 2000 contain at least one environmental clause, and $78.4 \%$ includes at least one clause addressing particular environmental concerns such as whaling, waste management, etc $^{(8)}$. Thus PTAs can be considered a subset of environmental agreements. The combined abundance of IEAs and PTAs is so prevalent that some experts in environmental governance do not hesitate to speak about "treaty congestion"(9).

Not all the treaties, however, have equal incentives for their enforcement. For two key reasons it is expected IEAs to have a different impact from that of the environmental clauses of PTAs. Firstly, PTAs with environmental provisions by their very nature connect trade and the environment. If this relation is essential for one party to a PTA, the other party may be given an opportunity to follow environmental legislation to protect this PTA and to obtain preferential access to a foreign market. Some multilateral IEAs do have trade controls, but they are limited to some goods, and only have clear incentives for domestic legislation to be implemented. Second, PTAs usually rely on compliance mechanisms more efficient than IEAs. In certain cases, if it fails to enforce its environmental commitments, a party to a PTA may potentially face monetary or trade sanctions. This

\footnotetext{
(4) Ibid.

(5) Mitchell (2020)

(6) Egger (2013).

(7) Jinnah (2011).

(8) Morin, Blouin (2019)

(9) Anton (2013)
} 


\section{Agrárne}

Figure 2: Rates of Successfully Completed IEA Negotiations
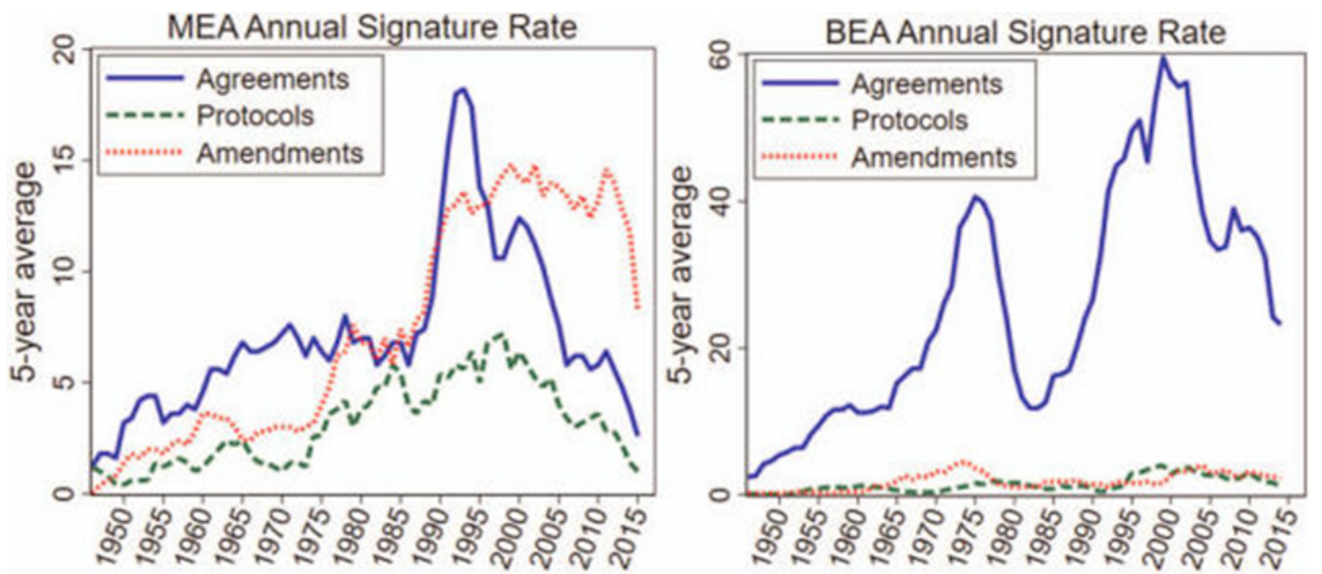

Source: Mitchell et al. (2020)

is almost unheard of when it comes to making environmental treaties. Instead, most IEAs rely on enforcement management processes, such as capacity building, accountability, and political dialogues ${ }^{(10)(11)}$.

Previous empirical research reviewing multilateral environmental agreements either centred primarily on factors affecting the decision of a single country to ratify a particular environmental treaty ${ }^{(12)}$ or considered a subset of agreements ${ }^{(13)}$. General findings indicate that richer countries have a more competitive political structure, are more open to trade and are more likely to collaborate and ratify a MEA.

GDP, distance and preferential trade agreements, variables that generally clarify well bilateral international trade flows, are also strong predictors of the probability that two countries will have a multilateral agreement on the environment and the number of agreements they have. Countries which trade more among themselves are more likely to be parties to at least one environmental agreement. Countries reducing pollution or preserving endangered species can suffer economic losses. Perhaps the most widely cited claim in opposition to pollution-restraining agreements is that limiting pollutant emissions such as carbon dioxide could harm firm competitiveness in global markets as new regulations raise production costs. In addition, participating in some environmental agreements, given new regulations, can result in less trade between states. As a result, countries that trade more with each other could avoid entering MEAs together, as that could have a negative effect on them. On the other hand, when the economic relations are strong, it could be easier for countries to align their economic and environmental policies. Two countries can jointly address environmental and economic concerns, because these linkages can ensure greater cooperation on both concerns. A nation which is not interested in protecting the environment can be able to do so if it can enjoy benefits from reduced trade barriers from its trading partners. Countries with large economic

\footnotetext{
(10) Chayes (1995).

(11) Tallberg (2002).

(12) Fredriksson, Gaston (2000).

(13) Davies, Naughton (2014).
}

interactions have more chances of such relations than countries with less interactions. In addition, countries may suffer non-environmental costs if they choose not to cooperate on an environmental agreement ${ }^{(14)}$. A nation may be disqualified from a potential trade deal for example if it fails to comply on an environmental deal. Conversely, due to an environmental agreement, foreign trade will increase. It may happen when an agreement is signed by one of the signatories promising to comply with the higher environmental requirements already in force in the other signatory. In such an environment, one country is increasing its standards and allowing its businesses to enter a market that used to be inaccessible to them, leading to increased trade between the two nations ${ }^{(15)}$.

The International Environmental Agreements Data Base (IEADB), launched in 2002, catalogues the documents, memberships, and design features of more than 3,000 multilateral and bilateral environmental agreements. Using IEADB data, we can have a thorough overview of the evolution of international environmental law, including how the number, subjects and IEA state membership has changed over time.

While the 1972 United Nations Conference (UNCHE) is frequently viewed as having kick-started international environmental law ${ }^{(16)}$, by 1950, states had signed over 250 IEAs. Figure 2 shows the five-year moving average of the signing of signed original agreements, protocols and amendments, showing states agreeing far more original bilateral environmental agreements (BEAs) than multilateral environmental agreements (MEAs) but changing them less regularly through protocols and amendments.

Around the time of UNCHE, states negotiated several BEAs, and both MEAs and BEAs around the time of the 1992 UN Conference on Environment and Development. Early MEAs and BEAs were dominated by species-related issues about overfishing, marine mammals and other wildlife, and trade threats to agricultural plants and animals, with pollution and freshwater resources only gaining serious attention after the

\footnotetext{
(14) Besedes, Johnson, Tian (2019)

(15) Ibid.

(16) Joyner (2005).
} 


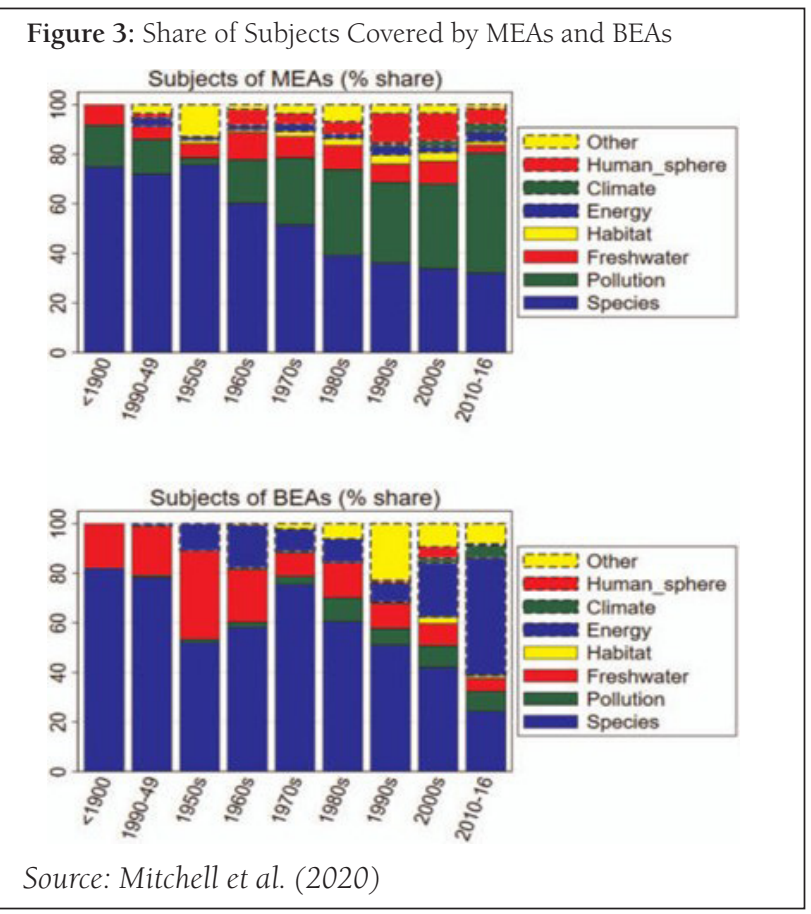

$1970 s^{(17)}$. Subjects have continued to diversify, with one third of IEAs now addressing animals, one third addressing pollution and energy, and the remaining third covering a number of other concerns (Figure 3).

When counting lineages rather than individual IEAs, the IEA landscape appears different. Mitchell ${ }^{(18)}$ coined the term lineage as a legal counterpart to the definition of a system, describing it as a series of "agreements, protocols, and amendments that alter, expand, substitute, or directly originate from one or more original agreements. The IEADB put more than 1,300 MEAs into 290 such lineages, with BEAs to be assigned in the future. These groupings record when a collection of states first discusses an environmental issue and how they over time alter their efforts. Thus, the tradition of "ozone protection" started with the Vienna Convention in 1985 and was amended by the Montreal Protocol of 1987 and eighteen modifications and changes.

As IEAs usually deal with the same subject within a lineage, we use the subject of the initiating agreement of each lineage as a proxy for when a group of states first effectively discuss a subject within a regional or global environment. Figure 4 graphs lineage-initiating agreements, showing how the range of subjects discussed by lineages has shifted, as either states take on new environmental issues or states in one region emulate initiatives in other regions to resolve a given problem. Lineage sizes (the number of IEAs each includes) represent very different approaches to governance. Of the 290 lines most ( 70 percent) are not complex regulatory initiatives and include only one initial MEA and one or two modifying protocols or amendments. In comparison, each of the ten largest lineages comprises twenty or more MEAs, representing up to one-third of the 1,300 MEAs collectively. This variation probably reflects various factors, including the age of the lineage; changes in scientific knowledge;

\footnotetext{
(17) Balsiger, VanDeveer (2012).

(18) Mitchell (2003).
}

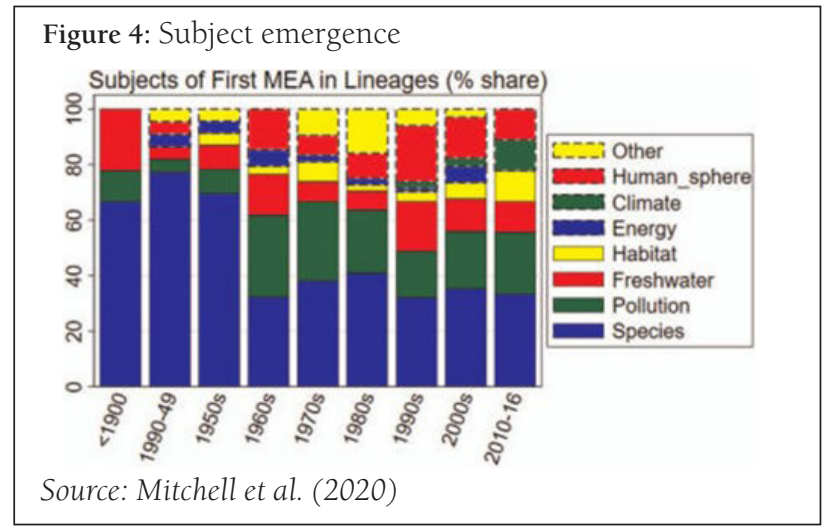

state preferences that favour strong initial action or prefer to make adjustments as support for action increases; adjustments in domestic and international concern about an environmental issue; and provisions in lineage-initiating IEAs that may allow, encourage or hinder frequent modifications.

In recent decades, the level of state participation in international environmental law, proxied by IEA membership counts, has increased rapidly. Total IEA membership growth reflects more states-negotiated MEAs and BEAs, more states in the international system (UN membership rose from 51 in 1945 to 193 in 2020), and more states entering more MEAs. Most IEAs are small: $80 \%$ are BEAs, $90 \%$ of MEAs have 10 members or fewer and only 30 MEAs have more than 100 members. Many MEAs are open to new members indefinitely, with membership usually increasing over time; thus, to accurately compare changes in MEA size over time, the memberships of each MEA is counted nine years after signature.

To resolve the fact that membership in protocols and amendments is mostly limited to members of the underlying agreement and is automatic for them, 457 MEA agreements were reviewed that have come into force and have at least nine years of membership data. Distinguishing 69 "global" MEAs (open to all UN members) from 388 MEAs limiting membership, reveals that, in their ninth year, global MEAs usually averaged less than thirty members until the 1980s, but have since averaged more than fifty. In comparison, MEAs limited to designated states, states in a specified area, or states with specified characteristics have never averaged more than 10 members (Figure 5).

Using these same MEAs to classify MEA memberships in the average state indicates that more IEAs are joining states. The approximately 140 UN members in the 1970s had ten MEA memberships; the total number of 180 or more UN members since the early 1990s has reached 50 memberships, with some approaching 100 and even new states having 10 to 20. The 10 states with the most MEA memberships are all European states in the high-income group of the World Bank, with each of the 457 MEAs assessed having joined $25 \%$. At least $15 \%$ of these MEAs have entered another 28, including states from all continents and 9 that are not high in revenue. This geographic and economic diversity represents various pressure on states to join IEAs including domestic environmental issues, foreign political pressure, and financial opportunities included in some MEAs. ${ }^{(19)}$

(19) Mitchell (2020). 


\section{Agrárne}

Figure 5: Average Year 9 Memberships in 69 Global and 388 Non-global MEA Agreements
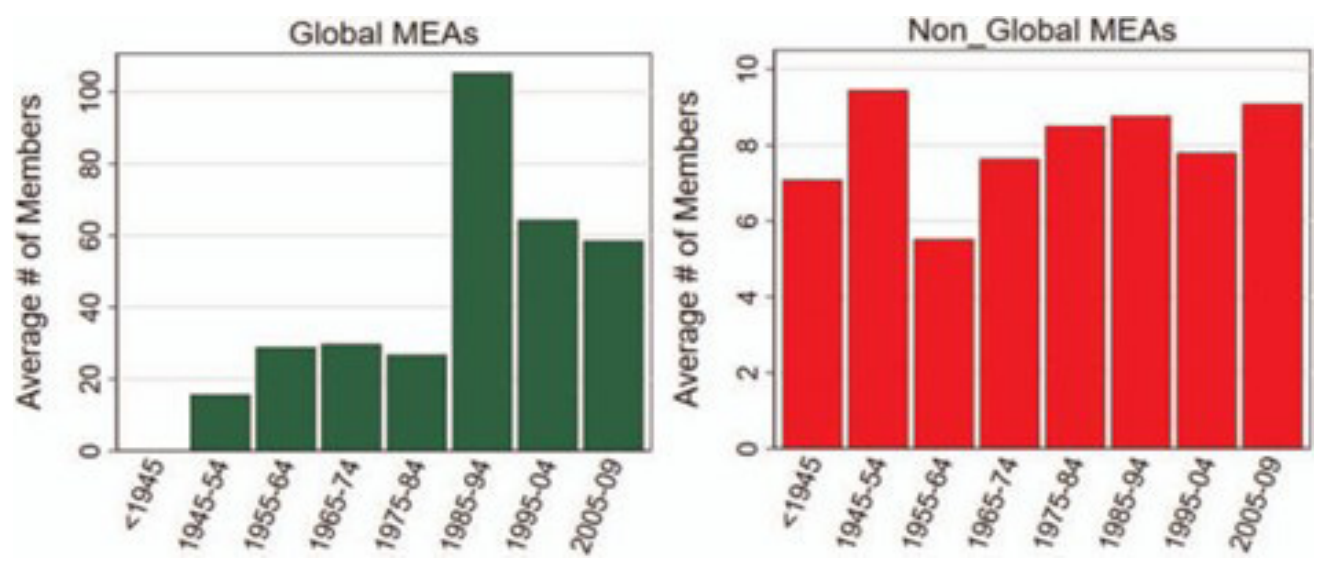

Source: Mitchell et al. (2020)

\section{Conclusions}

Researchers used data regarding IEADB membership to examine state behaviour. For example, Andonova, Hale, Roger(20) consider that state IEA ratifications provide a specific proxy for cooperation on the environment that helps explain the form of transnational climate governance. States, especially low-income states, tend to introduce new environmental regulations during periods when they join other IEAs ${ }^{(21)}$ and the annual environmental reputation score of a state (the share of MEAs that it has joined) predicts better than its economic power if its trade agreements contain environmental provisions ${ }^{(22)}$.

Comparing 67 MEAs to a set of non-environmental UN treaties, Axelrod ${ }^{(23)}$ considered the former to be more deferential to trade and other areas of international law. Analysing 300 IEAs chosen to include health-related provisions ${ }^{(24)}$ it was revealed the significant, previously unrecognized contributions of IEAs to global health governance, and it was found that the current MEAs provide clear normative foundations for negotiating a new treaty on sustainable mineral resource use.

The IEAs have helped reshape the content and mechanisms of global environmental governance, encouraging the participation of transnational and sub-national environmental actors and incorporating environmental concerns into trade agreements, development banks and other non-environmental institutions

\section{References}

1. Andonova, L. B., HALE, T. N., ROGER, Ch. B. 2017. National Policy and Transnational Governance of Climate Change: Substitutes or Complements? In International Studies Quarterly, vol. 61, no. 2, pp. 253-268.

2. ANTON, D. 2013. Treaty Congestion in Contemporary International Environmental Law. In Routledge Handbook of Interna-

\footnotetext{
(20) Andonova, Hale, Roger (2017).

(21) Morin, Blouin (2019).

(22) Ibid.

(23) Axelrod (2011)

(24) Morin, Blouin (2019).
}

tional Environmental Law. Abingdon, UK: Routledge.

3. AXELROD, M. 2011. Savings Clauses and the "Chilling Effect": Regime Interplay as Constraints on International Governance/ Law. In Managing Institutional Complexity: Regime Interplay and Global Environmental Change, edited by Sebastian Oberthur and Olav Schram Stokke, 87-114. Cambridge, MA: MIT Press.

4. BALSIGER, J., VAN DEVEER, S. 2012. Introduction: Navigating Regional Environmental Governance. In Global Environmental Politics, vol. 12, no. 3, pp. 1-17.

5. BESEDES T., JOHNSON E., TIAN X. 2019. Economic Determinants of Multilateral Environmental Agreements. In Int Tax Public Finance (2020).

6. BRANDI, C., MORIN, F. 2019. When Do International Treaties Matter for Domestic Environmental Legislation? In Global Environmental Politics, vol. 19, no. 4, pp. 14-44.

7. DAVIES, R., NAUGHTON, T. 2014. Cooperation in environmental policy: A spatial approach. In International tax and public finance, vol. 21, no. 5, pp. 923-954.

8. EGGER, P. 2013. Impacts of Trade and the Environment on Clustered Multilateral Environmental Agreements. In The World Economy, vol. 36, no. 3, pp. 331-348.

9. FREDRIKSSON, P., GASTON N. 2000. Ratification of the 1992 Climate Change Convention: What Determines Legislative Delay? In Public Choice, vol. 104, no. 3-4, pp. 345-368.

10. CHAYES, A. 1995. The New Sovereignty: Compliance with International Regulatory Agreements. Cambridge, MA: Harvard University Press.

11. JINNAH, S. 2011. Strategic Linkages: The Evolving Role of Trade Agreements in Global Environmental Governance. In The Journal of Environment and Development, vol. 20, no. 2, pp. 191-215.

12. JOYNER, Ch. C. 2005. International Law in the 21st Century: Rules for Global Governance. Lanham, MD: Rowman and Littlefield.

13. KOIVUROVA, T. 2014. Introduction to International Environmental Law, Routledge, 240 p.

14. MITCHELL, B. 2003. International Environmental Agreements: A Survey of Their Features, Formation, and Effects. In Annual Review of Environment and Resources, vol. 28, pp. 429-461.

15. MITCHELL, R. B. 2020. International Environmental Agreements Database Project. https://iea.uoregon.edu. Search engine: Google. Keywords: IEA, database. Retrieved: 05/01/2020.

16. MORIN, J., BLOUIN, C. 2019. How Environmental Treaties Contribute to Global Health Governance. In Globalization and Health, vol. 15, no. 1, Article 47.

17. TAllBERG, J. 2002. Paths to Compliance: Enforcement, Manage- 
ment, and the European

18. The Convention on the Conservation of Migratory Species of Wild Animals (1972): http://www.cms.int/about/intro.htm Search engine: Google. Keywords: convention, migratory. Retrieved: 04/26/2020.

19. UNITED NATIONS. 1969. Vienna Convention on the Law of Treaties Search engine: Google. Keywords: convention, treaties Retrieved: 04/30/2020
Contact address/ Kontaktná adresa

Dr. Zoltan Szira, PhD. - associate professor

Hungarian University of Agriculture and Life Sciences,

Institute of Agriculture and Food Economics,

e-mail: szira.zoltan@uni-mate.hu

Dr. Erika Varga, Phd. - associate professor

Hungarian University of Agriculture and Life Sciences,

Institute of Rural Development and Sustainable Economy,

e-mail: Erika.varga@uni-mate.hu

Hani Alghamdi - PhD candidate

Hungarian University of Agriculture and Life Sciences,

Doctoral School of Business and management

e-mail: alghamdi.hani84@gmail.com

\section{Dr. Kinga Bárdos, Phd. - senior lecturer}

Esterházy Károly Catholic University,

Institute of Psychology,

email: bardos.kinga@uni-eszterhazy.hu 